Teemu Lahtonen

kulttuurihistorian maisteriopiskelija, Turun yliopisto

Anni Teppo

HuK, yleinen kirjallisuustiede, Turun yliopisto

\title{
LAPIN NOIDAT JA POHJOISEN TAIKA ELOKUVASSA VALKOINEN PEURA
}

Tarkastelemme tässä katsauksessa Erik Blombergin ohjaamaa kauhufantasiaa Valkoinen peura (Suomi 1952). Kansainväliselle yleisölle suunnattu elokuva antaa eksoottisen kuvan Lapista ja sen asukkaista. Pääosassa on nuori Pirita (Mirjami Kuosmanen), joka muuttuu valkoiseksi, miehiä tuhoavaksi noitapeuraksi. Elokuva alkaa seuraavalla laululla, joka alustaa tapahtumia:

Pieni piika, Lapin lapsi / syntynyt oli hangelle / kasvoi tyttö heinäkenkä / niin kuin nuori vaadin. Ei tiennyt isänsä kodossa / miehelähän mennessänsä / että oli noita synnyltänsä / vatsassaan paha valta. Kermikän seidalle uhrasi / Maddar-Ahkkalle valkovasan / siitä peurana tunturiin juoksi / kunnes koitti hetki. Vasama valkoisen lävisti / siihen nukkui heinäkenkä / hanki hyinen peittehenä / lumipielus pään alla.

Elokuvan alussa Pirita menee naimisiin Aslak-nimisen poromiehen kanssa. Nainen kokee kuitenkin jäävänsä vähälle huomiolle avioelämässä ja päätyy shamaanin puheille. Seuraa loitsu, jonka ansiosta kukaan poromies ei pysty vastustamaan Piritaa - lisäksi tämä muuttuu aina täydenkuun aikaan valkoiseksi poroksi, joka tuhoaa lumoamansa miehet. Lopulta kylän miehet päättävät lopettaa noitapeuran, ja Piritan aviomies Aslak surmaa vaimonsa tietämättä tämän noitaidentiteetistä.

Valkoinen peura on arvostettu ja keskustelua herättänyt kotimainen elokuva. Pohdimme millaisin eri elokuvallisin keinoin saamelaisia ja Lappia representoidaan elokuvassa ja näiden representaatioiden ongelmallisuutta. Analysoimme myös Valkoisen peuran musiikkia ja kuvausta. Lopuksi käymme läpi elokuvan vuosien saatossa saamaa kritiikkiä. Millainen elokuvan vastaanotto on ollut? Millainen se on nykypäivänä?

Lappi aiheena on kiehtonut ja kiehtoo edelleen useita suomalaisia elokuvantekijöitä. Suomessa on tehty monia Lappi-aiheisia elokuvia 1900-luvun alkupuolelta lähtien. Esimerkiksi Noidan kirot (1927), Aila - Pohjolan tytär (1951), Skierri (1982), Poika ja ilves (1998), Rare Exports (2010) ja aiheenamme oleva elokuva ovat genreiltään moninaisia: joukosta löytyy niin melodraamaa kuin toimintaelokuvaakin.

Monissa elokuvissa korostuu Lapin luonnon kauneus ja koskemattomuus. Toisaalta Lappia on läpi historian mystifioitu: antiikin Kreikassa kerrottiin tarua kaukana pohjoisessa sijaitsevasta Hyperborean maasta, jossa asuu kolmimetrisiä ihmisiä. Heli Saarisen mukaan Lappi-myytin keskeiseen kuvastoon kuuluu muun muassa lumiset tunturit, saamelaisten elämä poronhoitajina sekä muinaisuskon ja kristinuskon keskinäinen hankaus. Kaikki nämä ovatkin nähtävissä myös Saarisen tutkimassa 


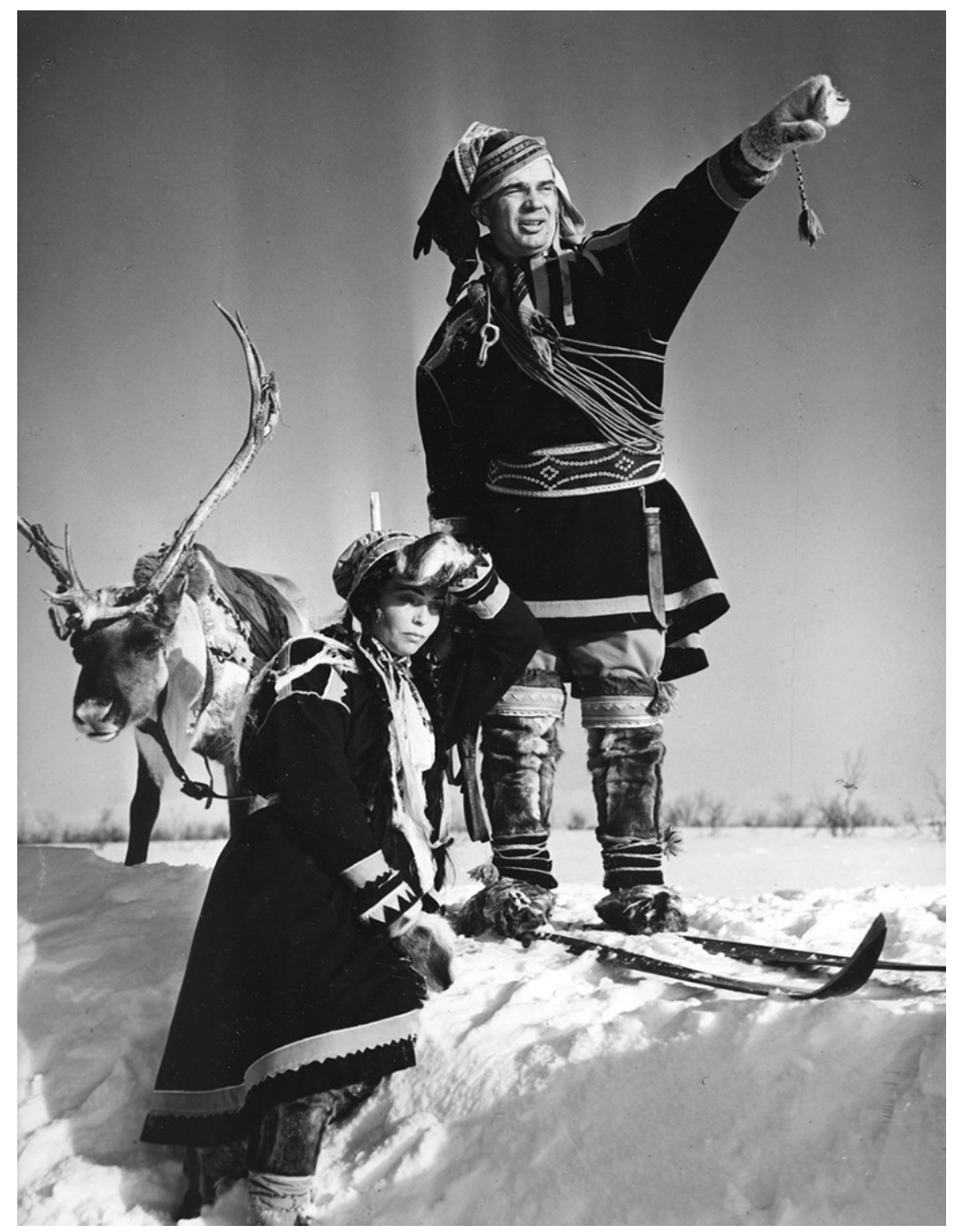

Pirita (Mirjami Kuosmanen) ja hänen aviomiehensä Aslak (Kalervo Nissilä). Kuva: Elonet.

Valkoisessa peurassa. Saarinen painottaa myös mielikuvaa saamelaisista noitina - se on kulkeutunut 1950-luvun elokuvaan aina 1500-luvulta asti. (Saarinen 2012, 56-57.)

Vaikka moni suomalainen elokuva sijoittuu Lappiin tai keskittyy muuten alueen tematiikkaan, on Lapin alkuperäisasukkaita nähty elokuvatuotannoissa hyvin vähän. Saamelaisia hahmoja on kyllä nähty valkokankaalla aina 1900-luvun alusta alkaen (Lehtola 2000, 12), mutta saamelaisten oma elokuvatuotanto on saanut alkunsa vasta 1980-luvulla. Ennen tätä heidät oli kuvattu aina ulkopuolisen näkökulmasta. Ensimmäinen saamelaisten tekemä elokuva, Nils Gaupin ohjaama Ofelaš (Tiennäyttäjä), esitettiin ensimmäisen kerran vuonna 1987. (Lehtola 1997, 124.)

\section{Mielikuvien Lappi - saamelaisten ja muinaisuskon (mis)representaatio}

Saamastaan aikalaissuosiosta huolimatta Blombergin elokuva tarjoaa haitallisia stereotypioita, jotka vähättelevät ja yksinkertaistavat saamelaisten kulttuuria ja muinaisuskoa. Stuart Hallin $(1997 b, 15)$ mukaan representaatiolla tarkoitetaan sitä, kun kieltä käytetään jonkin merkityksellisen asian esittämiseksi tai uudelleen esittämiseksi. Representaatio on siis tärkeä osa prosessia, jossa merkitykset liikkuvat 
eri kulttuurien välillä (Hall 1997b, 15). Toki täytyy ottaa huomioon, että elokuva on fiktiota, eikä siis välttämättä pyri antamaan kuvaamastaan aiheesta todellista kuvaa. Christine Gledhill $(1997,340)$ pohtii, että juuri tämä asenne johtaa virheelliseen ajattelutapaan: elokuvia pidetään helposti vain harmittomana viihteenä, vaikkei asia näin ole. Elokuvat, kuten muukin meitä ympäröivä maailma ja kulttuuri, muokkaavat ja ruokkivat mielipiteitämme ja ennakkoluulojamme, etenkin kun on kyse meille vieraista asioista. Representaatiota - ja varsinkin misrepresentaatiota eli vääristyneen esityksen antamista - voidaan ajatella yhtenä avaintekijänä niin sanotun symbolisen vallan ja väkivallan harjoittamisessa (Hall 1997a, 259).

Yhtä lukuun ottamatta kaikki elokuvan hahmot ovat saamelaisia: ainoastaan forstmestari on etelästä kotoisin. Näyttelijät eivät siis pysty antamaan autenttista representaatiota - he ovat suomalaisia ja puhuvat lisäksi suomen kieltä. Pohjoisen asukkaat on kuvattu stereotyyppisesti - näyttelijät on esimerkiksi puvustettu väljähköillä ja pitkillä talviasuilla, jotka pyrkivät luomaan illuusion hahmojen pienikokoisuudesta (Saarinen 2011, 116). Myös kuvakulmaan on kiinnitetty huomiota: saamelaiset hahmot kuvataan kuvakulmasta, joka korostaa tyypillisinä ajateltuja piirteitä kuten korkeita poskipäitä (Saarinen 2011, 125, 163).

Piritan hahmo kuvataan rohkeana ja sukupuolirooleja uhmaavana. Elokuvan noitanaisen voisi nähdä pohjaavan myös itäsaamelaiseen perinteeseen, jossa naisen roolina on ollut toimia yhdistävänä henkilönä ihmisten ja eläinten maailmojen välillä (Lehtola 2000, 131). Tämä näkyy elokuvassa Piritan muodonmuutoksena eläimeksi sekä lukuisina eläinaiheisina viittauksina dialogissa. Esimerkiksi Aslakin saapuessa kosimaan Piritaa naisen isä toteaa: "Taitaa tulla naaraskarhun pyytäjiä." Aslak myös kutsuu Piritaa "lintusekseen".

Valkoinen peura antaa eksoottisen, kansainväliselle yleisölle suunnatun kuvan Lapista ja sen asukkaista. Elokuvan muodonmuutosteema on kuitenkin selkeästi saanut vaikutteita eurooppalaisen romantiikan aiheista. (Saarinen 2011, 234.) Piritan pakonomainen muodonmuutos peuraksi täydenkuun aikaan viittaa erityisesti ihmissusiin, ja valkean villipeuran houkutteleva ulkomuoto, joka paljastuukin tappavaksi, muistuttaa moderneja vampyyritarinoita. Innoitusta noituuden esittämiseen Blomberg kertoo saaneensa Arne Runebergin väitöskirjasta, joka käsittelee eurooppalaisissa kansantarinoissa esiintyvää noituutta. Runebergin mukaan noita ei aina tiedä olevansa noita, vaan noituus ikään kuin hallitsee kantajaansa. Blomberg ja Kuosmanen halusivat tehdä Lappiin sijoittuvan elokuvan, mutta ovat itsekin todenneet, että aiheensa puolesta tarinan olisi voinut sijoittaa minne tahansa maailmassa. (Elokuva-Aitta 1951, 6-7.) Tämä kuvastaa hyvin muodonmuutosteeman universaaliutta, vaikka elokuva sijoittuukin konkreettisesti Lappiin ja saamelaisyhteisöön. Elokuvassa yhdistyvät siis eksoottinen ja universaali, etenkin ulkomaalaisen katsojan näkökulmasta.

Elokuvassa esitetään myös saamelaisten muinaisuskontoa. Kyläyhteisön shamaani, Tsalkku-Nilla, kuvataan höperönä, humalaisena ukkona. Mies tarttuu ärhäkästi Piritan lahjuksena tuomaan pulloon ja kaataa suuren osan nestettä saman tien kurkkuunsa. Sen jälkeen Tsalkku-Nilla alkaa puhua lemmenjuomasta: "Lemmenjuomaa vai lemmenjuomaa? Sitähän ne nuoret naiset ja vanhatkin. Mies tunturissa, nunnunnuuh." Repliikin jälkeen seuraa erilaista lällättelyä ja nunnuttelua. Tässä kohtaa representaatio muuttuu ongelmalliseksi, sillä se on loukkaavaa ja väheksyvää saamelaisten muinaisuskontoa kohtaan.

Saarisen mukaan kristinuskoon viittaavaa kuvastoa nähdään ensi kerran Valkoisen peuran loppupuolella. Kohtauksessa vampyyrilta näyttävä Pirita hiipii kohti miestään kuun valaisemassa pirtissä ja astahtaa ikkunan varjosta muodostuneen ristiä muistuttavan kuvion päälle. Myöhemmin seuraa vielä hääkohtaus kirkosta. Elokuvan päättyessä Pirita - noitapeura, pakana - saa surmansa, mikä vertautuu kaikenlaisen 


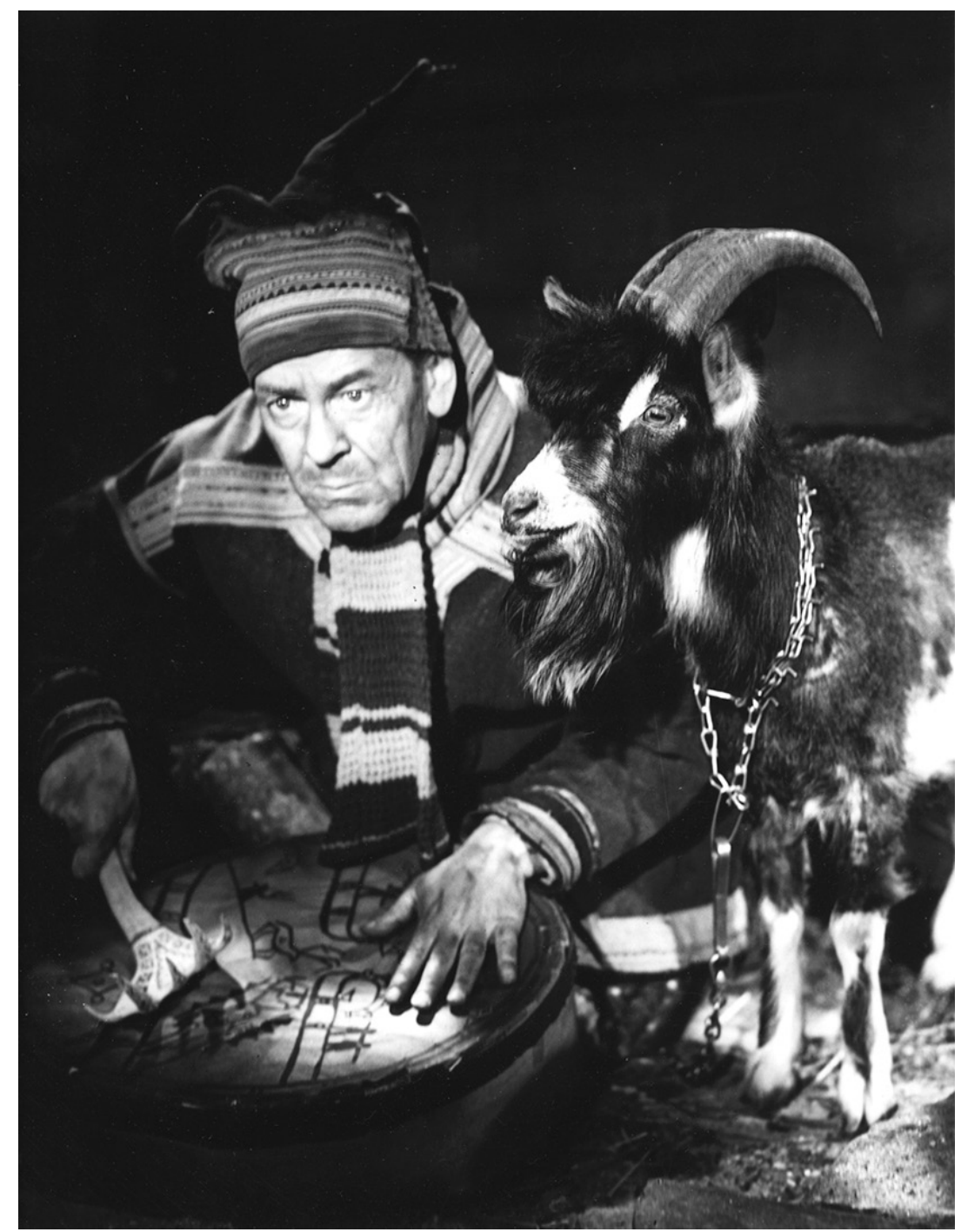

Vierailulla shamaani Tsalkku-Nillan (Arvo Lehesmaa) luona. Kuva: Elonet.

pakanuuden tuhoamiseen kristinuskon tieltä. (Saarinen 2011, 173-174.) Uskontojen representaatio onkin kyseenalaista elokuvassa: saamelaisten oma muinaisusko kuvataan pakanallisena ja viinanhuuruisina temppuina, mutta kristinuskon kuvaus ei vaikuta saavan tämänkaltaisia vivahteita. Kirkossa vietettävät häät vaikuttavat täysin asiallisilta verrattuna esimerkiksi shamaani Tsalkku-Nillan kuvaukseen.

Tsalkku-Nilla kuvataan erakkona, hontelossa tuvassa asuvana viinapalkkiosta taikatemppuja tekevänä ukkona. Samanlaista vääristynyttä kuvaa saamelaisuudesta on tuotettu esimerkiksi 1980-luvun Hymyhuulet-sketsisarjassa, jonka saamelaishahmot nousivat vastikään jälleen puheenaiheeksi sarjassa näytelleen Pirkka-Pekka Peteliuksen pyydettyä sketsejä anteeksi saamelaisyhteisöltä (Rasmus 2019). Noora Kallioniemi ja Niina Siivikko käsittelevät Valkoista peuraa ja Hymyhuulia yhdistävää ongelmallisuutta tarkemmin tässä Lähikuvan numerossa olevassa artikkelissaan "Anteeksipyyntöjä ja uudelleenkehystämistä: 2010-luvun keskustelu audiovisuaalisen kulttuurin saamelaisrepresentaatioista Suomessa". Saamelaisten shamaanit, eli noaidit, olivat linkkejä ihmisten todellisuuden ja tuonpuoleisen todellisuuden välillä. Shamaanit pyrkivät kyvyillään auttamaan yhteisöään hätätilassa, kuten sairauden hoitamisessa, ja siksi he olivat yhteisönsä kunnioitettuja jäseniä. (Saarinen 2011, 167.) Katsojalle ei kuitenkaan välity tällaista kuvaa shamaaneista, jolloin mielikuva voi jäädä joidenkin katsojien kohdalla todella vääristyneeksi. 
Astuminen Tsalkku-Nillan tupaan on visuaalisesti kuin siirtymä toiseen maailmaan. Suuri osa elokuvan tapahtumista siihen asti - ja myös sen jälkeen - sijoittuu ulkoilmaan, lumisen Lapin puhtaaseen valkoisuuteen. Noidan asumus taas on tumman nokinen, nuotion epätasaisessa valossa häilyvä, pelottava ja epäjärjestyksellinen paikka. Noidan kuvaus on karikatyyrinen, lähes huvittava, mikä vähentää myös pelottavuuden vaikutelmaa. Noita juo pitkän ryypyn Piritan tuomasta viinapullosta, naureskelee ja lällättelee sekä lyö rumpuaan. Tunnelma muuttuu jälleen pelottavaksi Piritan oman noituuden halkaistessa Tsalkku-Nillan rummun. Vanha noita kavahtaa kauemmas ja Piritaa kuvataan nuotion yli, kuin uusi noita olisi juuri syntynyt tulen lieskoista.

Noaidit pystyivät myös muuntautumaan tietyiksi eläimiksi - kuten linnuksi, kalaksi tai poroksi - ja liikkumaan eläimenä kätevämmin kuin ihmisenä, tehden siten niin kutsutun sielunmatkan. (Saarinen 2011, 175.) Erona Valkoisen peuran tapahtumissa ja saamelaisessa perinteessä on kuitenkin se, että Piritan muuntuminen peuraksi on ihmissusimainen, pakonomainen muutos. Shamaanit taas muuntuvat omasta tahdostaan, rumpunsa avulla suoritetun rituaalin myötä.

Musiikki on Valkoisessa peurassa suuressa roolissa. Elokuvassa on melko vähän dialogia, ja teos onkin lähestulkoon läpisävelletty. Elokuvan säveltäjä Einar Englund pohjasi musiikkinsa Ilmari Krohnin 1800-luvun lopulla kokoamaan saamelaismusiikin teokseen. Anu Juva pitää Englundin käyttämää materiaalia aitona ja kiinteänä osana elokuvan kuvaamia paikkoja ja ihmisiä (Juva 1995, 242). Antti-Ville Kärjän mielestä kyseessä on kuitenkin eräänlainen kaksoisassimilaatio. Joiut ovat alun perin ainoastaan laulettu musiikkilaji, eikä perinteistä joikua säestä kuin enintään shamaanin rumpu. Joikua ei ole muodostettu vahvan rakenteellisen kehyksen sisään kuten länsimaista - etenkin populaaria - musiikkia. Myös improvisaatio on osa joikuperinnettä. Jo Ilmari Krohnin oli siis muokattava kuulemaansa musiikkia voidakseen nuotintaa sen. Englund taas muokkasi Krohnin kokoelmasta löytämäänsä musiikkia, jotta se sopisi elokuvan julkaisuajalle melko tyypilliseen elokuvamusiikin instrumentaatioon. Tällöin musiikin saamelainen aitous jäi kauas taakse. (Kärjä 2007, 155; Hirvasvuopio-Laiti \& Siivikko 2019, 199.)

\section{Elokuvan vastaanotto}

Valkoinen peura on ollut arvostettu elokuva niin Suomessa kuin ulkomaillakin. Elokuvaa myytiin yhteensä yhdeksään Euroopan maahan, Etelä-Amerikkaan ja Yhdysvaltoihin (Suomen kansallisfilmografia 1992, 512). Eritoten sen musiikki ja kuvaus herättivät ihastusta (ks. esim. HS 27.7.1952; Schemeil 1953). Elokuvan julkaisuajankohta sijoitettiin taktisesti Helsingin olympialaisten aikaan, ja se suunnattiin kansainväliselle yleisölle (Saarinen 2011, 46). Ulkomailla kiinnostuttiin elokuvasta, olihan se eksoottinen valkoisine maisemineen ja poroineen. Elokuva pääsi esitettäväksi Cannesin elokuvafestivaaleille ja se sai suosionosoituksia jo esityksen aikana (Schemeil 1953). Valkoisesta peurasta julkaistiin arvio yhdysvaltalaisessa Variety-lehdessä, jossa muun muassa kehuttiin elokuvan kuvausta ja näyttelijäntyötä (Variety 13.5.1953).

Elokuviin keskittyvässä aikakauslehti Elokuva-Aitassa ilmestyi vuonna 1952 Valma Kivitien kirjoittama kritiikki, jossa Valkoinen peura sai viisi tähteä. Kivitie kirjoitti, että elokuva "luotaa syvälle alkukantaisten ihmisten mystillisiin taikoihin ja uskomuksiin." Kritiikissä ei siis lainkaan problematisoitu elokuvan antamaa representaatiota alkuperäiskansasta, vaan päinvastoin stereotyyppistä representaatiota korostettiin puhumalla "alkukantaisista" ihmisistä. Kivitie vertasi monen muun tavoin elokuvaa Aino Kallaksen romaaniin Sudenmorsian (1928) ja Robert Louis 
Stevensonin pienoisromaaniin Strange Case of Dr Jekyll and Mr Hyde (suom. Tohtori Jekyll ja Mr. Hyde,1886). Hän myös korosti elokuvan seksuaalisuuteen syventyvää luonnetta. Kivitien käyttämän sanavalinnan "salatut mystilliset kurimukset" voisi tulkita esimerkiksi viittauksena juuri seksuaalisuuteen ja sen kiellettyyn luonteeseen: "Siitä huolimatta Valkoinen peura on itsenäinen, ihmissielun merkillisiin kuiluihin ja salattuihin mystillisiin kurimuksiin pohjaava tarina." Lapin noidan näyttelijää, Arvo Lehesmaata, Kivitie kuitenkin moitti roolisuorituksestaan: "[Lehesmaa] tyytyy tekemään tällaisen köykäisen satunäytelmän noidan mahtavasta Lapin tietäjästä." (Kivitie 1952, 20-21.) Kivitie siis jollain tasolla ymmärsi, että shamaanin representaatio on ongelmallinen ja jopa loukkaava. Hänen mielestään syypää oli kuitenkin näyttelijä, eikä käsikirjoittaja tai ohjaaja.

Vaikka elokuva on klassikko, siihen suhtaudutaan nykyisin aikaisempaa kriittisemmin. 1990-luvulla elokuvaa on tarkasteltu ja arvioitu esimerkiksi feministisestä näkökulmasta, jolloin Piritan hahmo on nostettu yksityiskohtaisempaan tarkasteluun (ks. Salminen 1992). Nuori Voima -lehteen kirjoittanut Kari Salminen $(1992,38)$ on pohtinut elokuvan luonnetta ja kyseenalaistanut sen maineen kauhuelokuvana:

Mutta Valkoinen peura ei ole varsinainen kauhuelokuva. Se ei vaivaudu rakentelemaan samastumiseen kutsuvaa normaaliuden kudosta, jonka hirviö sitten ilmestymisellään rikkoisi. Valkoinen peura on pikemminkin myyttiseen aikaan ja tilaan etäännytetty allegoria naisesta ja miehestä, seksuaalisuudesta ja sen kesyttämisen mahdottomuudesta.

Salminen nostaa esiin myös toisen kiintoisan seikan: Piritan noituudesta tulee ongelma vasta sitten, kun hänet vangitaan patriarkaalisen yhteiskunnan tapaan avioliittoon. Pirita on vaarallisesti seksuaalinen nainen, joka ei sovellu kulttuurinsa

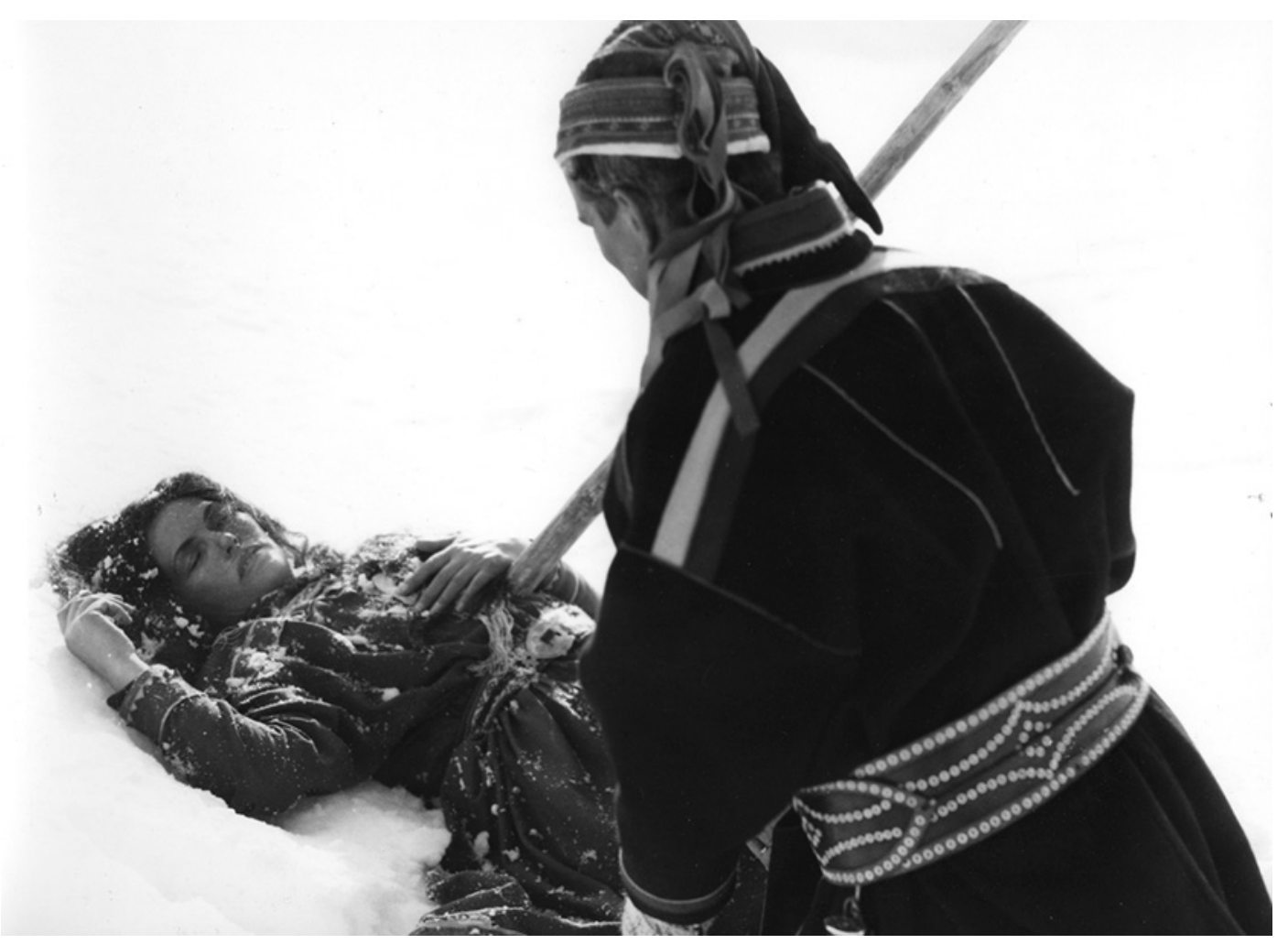

Aslak surmaa noitapeuran epätietoisena siitä, että kyseessä on hänen vaimonsa. Kuva: Elonet. 
valmiiksi asettamiin raameihin. (Salminen 1992, 38.) Salmisen tulkinnan pohjalta Valkoinen peura voidaan nähdä siis esityksenä universaalimmasta seksuaalisuuden kulttuurista ja naisen alistetusta roolista siinä.

2000-luvun puolella huomiota on kiinnitetty erityisesti elokuvan antamiin vääristäviin representaatioihin saamelaisista ja heidän uskonnostaan ja kulttuuristaan. Monet kirjoittajat ovat nostaneet keskusteluun myös kulttuurisen omimisen (ks. esim. Mikkonen \& Puukka 2018; Särmä 2017). Esimerkiksi saamelainen valokuva- ja videotaitelija Marja Helander kokee, että Valkoinen peura vahvistaa saamelaisuuteen liittyviä stereotypioita. Hänen mielestään elokuvan saamelaiskuvasto on "puolivillaista" ja "alkuperäiskansa esitetään pelkkinä porojenhoitajina, viinaan menevänä, seitaa palvovana joukkona, joka ei toimi järkevästi". (Melamies 2018.) Monessa elokuvaa käsittelevässä kirjoituksessa - joihin tässäkin katsauksessa olemme viitanneet - on tartuttu kuvattuihin perinteisiin, kuten vaatetukseen ja häämenoihin. Saamelaisten alaryhmät eroavat tavoiltaan merkittävästi toisistaan, ja Valkoiseen peuraan on lainattu piirteitä vaihtelevasti lähes kaikilta. Lainatut asiat on kuitenkin yhdistetty niin, etteivät esimerkiksi elokuvan häät lopulta vastaa minkään ryhmän todellista perinnettä. (Lehtola 2000, 138-139.)

\section{Lopuksi}

Olemme käsitelleet Valkoista peuraa representaation ja sen saamien arvioiden näkökulmasta. Elokuva misrepresentoi saamelaisia ja heidän kulttuuriaan ja uskontoaan erilaisin elokuvallisin keinoin. Aikalaiskritiikissä näihin stereotypioihin ja loukkaaviinkin kuvauksiin ei juurikaan puututtu - oikeaa tietoa saamelaisuudesta ei ollut riittävästi niiden problematisoimiseen. Sittemmin moni on nostanut elokuvan ongelmallisuuden esiin juuri saamelaisten omasta näkökulmasta, kuten aiemmin mainittu Helander. Aikalais- ja nykykritiikkiä on mielenkiintoista seurata - kritiikkiä tarkastelemalla voi huomata ajan ja suhtautumistapojen sekä ymmärryksen muuttuneen. Välissä elokuvaa on arvioitu myös sukupuolen ja seksuaalisuuden näkökulmasta, jolloin nostettiin keskusteluun muun muassa Piritan hahmon vahva feministinen olemus. Vaikka Valkoinen peura epäonnistuu saamelaiskuvauksessaan osittaisen stereotyyppisyyden ja virheellisyyden takia (esimerkiksi uskontojen eriarvoistava kuvaus ja shamaanin hahmo), se onnistuu jollain tavalla kuitenkin kuvaamaan sukupuolten välistä epätasa-arvoa, ja tässä on otettava huomioon, että elokuva on tehty jo 1950-luvulla.

Toisen maailmansodan jälkeisessä Suomessa saamelaiskulttuuri joutui suuren suomalaistumis- ja suomalaistamispaineen alaiseksi. Saamelaisten kulttuuria arvostettiin, mutta se koettiin enemmänkin historiallisena muistona, joka haluttiin taltioida, mutta ei uudistaa. Suomen matkailukulttuuri innostui myös houkuttelemaan ulkomaisia turisteja esittelemällä mainoksissaan alkuperäiskansaa. (HirvasvuopioLaiti \& Siivikko 2019, 193-194.) Tämä näkyy myös Valkoisessa peurassa: elokuva suunnattiin kansainväliselle yleisölle alkuperäiskansan eksoottista vetovoimaa hyödyntäen samalla tavalla kuin matkailumainonnassa. Elokuva onnistuikin hurmaamaan ulkomaat, näytettiinhän sitä esimerkiksi Cannesin elokuvafestivaaleilla, ja sana kiiri jopa losangelesilaisen lehden elokuvien arvostelupalstalle. Suomalaistumis- ja suomalaistamispaineen vuoksi saamelaisten aikalaiskuvauksia itsestään ei kuitenkaan elokuvahistoriastamme juuri löydy.

Valkoinen peura on edelleen arvostettu kotimainen elokuva, mutta se herättää nykyään myös negatiivisia tunteita. Juuri siksi elokuva on noussut monen vuosikymmenen jälkeen uudestaan keskustelun kohteeksi - tällä kertaa kriittisemmästä ja tiedostavammasta näkökulmasta. Elokuvaa katsoessa on kuitenkin otettava huo- 
mioon sen syntykonteksti. Tietoisuus toisista kansoista ja muita kunnioittavasta representaatiosta on lisääntynyt huomattavasti. Asioista keskusteleminen ja niiden kyseenalaistaminen on kuitenkin edelleen tärkeää, kuten myös pyrkimys ymmärtää vieraita kulttuureja. Kuten Gledhill $(1997,340)$ toteaa, fiktio, ja siten myös elokuvat, eivät ole vain harmitonta viihdettä. Nykypäivän ihminen saa yllättävän usein tietonsa vieraista asioista jonkinlaisen kulttuurituotteen kautta, mikä sinänsä voi olla hyvä asia: tieto erilaisuuden olemassaolosta tavoittaa monen vastaanottajan. Tässä astuu kuvaan representaatio, ja sen mahdollinen, jopa tiedostamaton hyväksi käyttäminen. Kun välitetään merkityksiä erilaisista kulttuureista vastaanottajille, on tärkeää välttää stereotypioita tai loukkaavia kuvauksia.

Katsausartikkeli on toteutettu osin Turun yliopiston kulttuurihistorian oppiaineen järjestämän kurssin Kulttuurihistorian kirjoittaminen (2019) yhteydessä.

\section{Lähteet}

\section{Elokuva}

Valkoinen peura (1952). Ohjaus: Erik Blomberg. Käsikirjoitus: Mirjami Kuosmanen, Erik Blomberg. Päärooleissa: Mirjami Kuosmanen, Kalervo Nissilä. Tuottaja: Aarne Tarkas. Ensi-ilta: 25.7.1952 (Helsingissä). Kesto: 74 minuuttia. Perustuu Mirjami Kuosmasen alkuperäisaiheeseen.

\section{Kirjallisuus}

Elokuva-Aitta (1951) Noituuden taikakehä on Erik Blombergin ja Mirjami Kuosmasen uuden filmin taustana. No. 1.

Gledhill, Christine (1997) Genre and Gender: The Case of Soap Opera. Teoksessa Stuart Hall (toim.) Representation: Cultural Representations and Signifying Practices. Lontoo: SAGE Publications, 337-384.

Hall, Stuart (1997a) The Spectacle of the 'Other'. Teoksessa Stuart Hall (toim.) Representation: Cultural Representations and Signifying Practices. Lontoo: SAGE Publications, 223-279.

Hall, Stuart (1997b) The Work of Representation. Teoksessa Stuart Hall (toim.) Representation: Cultural Representations and Signifying Practices. Lontoo: SAGE Publications, 13-64.

Helsingin Sanomat (1952) Viikon filmejä. Helsingin Sanomat, 27.7.1952.

Hirvasvuopio-Laiti, Annukka \& Siivikko, Niina (2019) Saamelaisrenessanssin synty ja Nils-Aslak Valkeapään Joikuja-albumi (1968). Teoksessa Maarit Leskelä-Kärki; Marika Ahonen \& Niko Heikkilä (toim.) Toivon ja raivon vuosi 1968. Helsinki: Työväen historian ja perinteen tutkimuksen seura, 191-203.

Juva, Anu (1995) Valkokangas soi! Helsinki: Kirjastopalvelu Oy.

Kivitie, Valma (1952) Valkoisen peuran ennätyslaukka. Elokuva-Aitta 16.

Kärjä, Antti-Ville (2007) Suomalaisen lännenelokuvan musiikki. Teoksessa Henry Bacon, Anneli Lehtisalo \& Pasi Nyyssönen (toim.) Suomalaisuus valkokankaalla: kotimainen elokuva toisin katsoen. Helsinki: Like Kustannus, 137-166.

Lehtola, Jorma (2000) Lailasta Lailaan: tarinoita elokuvien sitkeistä lappalaisista. Inari: Kustannus-Puntsi. Lehtola, Veli-Pekka (1997) Saamelaiset: historia, yhteiskunta, taide. Inari: Kustannus-Puntsi.

Melamies, Elina (2018) Saamelaisuuden esittäminen on yhä ongelmallista - palkittu esikoisohjaaja Marja Helander kertoo miksi vääntelehti tuolissaan jyväskyläläiskuoron "joikatessa". Lapin Kansa, 17.6.2018. Saatavilla: <https://www.lapinkansa.fi/lappi/saamelaisuuden-esittaminen-on-yha-ongelmallista-palkittu-esikoisohjaaja-marja-helander-kertoo-miksi-vaantelehti-tuolissaan-jyvaskylalaiskuoronjoikatessa-201019848/> (Linkki tarkistettu 17.5.2020.)

Mikkonen, Nadja \& Puukka, Päivi (2018) Sulkapäähineen käyttö on kuuma aihe myös maailmalla - suomalainen mohawk: "sitä ei ole koskaan tarkoitettu kenen tahansa puettavaksi". Ye Uutiset, (30.4.2018) 2.5.2018. Saatavilla: <https://yle.fi/uutiset/3-10184919> (Linkki tarkistettu 17.5.2020.) 
Rasmus, Linnea (2019) Pirkka-Pekka Petelius pyytää anteeksi saamelaisia pilkkaavia sketsejään: "Olen valmis keskustelemaan myös muiden vähemmistöjen kanssa". Me Uutiset, 21.11.2019. Saatavilla: <https:// yle.fi/uutiset/3-11079638> (Linkki tarkistettu 17.5.2020.)

Saarinen, Heli (2012) Lappi-myytin kehittyminen keskiajan kuvastosta suomalaiseen elokuvaan. Kulttuurintutkimus vol. 29:1, 56-58.

Saarinen, Heli (2011) Valkoisen peuran myyttinen Lappi. Väitöskirja. Rovaniemi: Lapin yliopistokustannus.

Salminen, Kari (1992) Hyvä nainen on kuollut nainen. Valkoinen peura ja melofantastinen noitavaino. Nuori Voima 6, 36-39.

Schemeil, Jack (1953) “Valkoinen peura” sai suosionosoituksia kesken esityksenkin. Helsingin Sanomat, 21.4.1953.

Suomen kansallisfilmografia (1992) Valkoinen peura. Suomen kansallisfilmografia 4. Vuosien 1948-1952 suomalaiset kokoillan elokuvat. Helsinki: VAPK-kustannus, 508-513.

Särmä, Saara (2017) Kulttuurien omiminen ei ole tunnekysymys. Kansan Uutiset, 14.10.2017. Saatavilla: <https://www.kansanuutiset.fi/artikkeli/3791973-saara-sarma-kulttuurinen-omiminen-ei-oletunnekysymys> (Linkki tarkistettu 17.5.2020.)

Variety (1953) Film Reviews - Valkoinen peura. 13.5.1953. 